\title{
PROFESI SEORANG GURU
}

\author{
Farah Mu'thia \\ Email: 2010111220022@,mhs.ulm.ac.id \\ Program Studi Pendidikan Sejarah Fakultas Keguruan dan Ilmu Pendidikan \\ Universitas Lambung Mangkurat \\ Banjarmasin
}

\begin{abstract}
Abstrak
Profesi secara etimologi berasal dari kata "profession" yang berasal dari bahasa Latin "profesus" yang berarti mampu atau ahli dalam suatu bentuk pekerjaan. Profesi dapat diartikan sebagai suatu pekerjaan atau jabatan yang menuntut keahlian, yang didapat melalui pendidikan dan latihan tertentu, menurut persyaratan khusus memiliki tanggung jawab dan kode etik tertentu. Guru yang piawai dalam melaksanakan profesinya dapat disebut sebagai guru yang kompeten dan profesional. Hak dan kewajiban guru ini dituangkan dalam pasal UU No. 14 Tahun 2005 tentang guru dan dosen sehingga setiap guru mendapatkan perlindungan terhadap hak yang dimiliki dan kewajiban yang harus dilaksanakan. Kompetensi profesional merupakan kemampuan dasar yang harus dimiliki oleh guru. Di Indonesia penghargaan terhadap profesi guru belumlah sebaik kedua negara tersebut, akan tetapi sejak diterapkannya kebijakan sertifikat guru profesi guru mengalami kemajuan signifikan.
\end{abstract}

\section{PENDAHULUAN}

Profesi secara etimologi berasal dari kata "profession" yang berasal dari bahasa Latin "profesus" yang berarti mampu atau ahli dalam suatu bentuk pekerjaan. Profesi dapat diartikan sebagai suatu pekerjaan atau jabatan yang menuntut keahlian, yang didapat melalui pendidikan dan latihan tertentu, menurut persyaratan khusus memiliki tanggung jawab dan kode etik tertentu. Profesi juga diartikan sebagai suatu jabatan atau pekerjaan tertentu yang mensyaratkan pengetahuan dan keterampilan khusus yang diperoleh dari pendidikan akademis yang intensif. Berdasarkan beberapa kriteria tersebut, maka profesi merupakan bidang pekerjaan tertentu yang dinilai telah memenuhi kriteria. Dengan kata lain, tidak semua pekerjaan dapat disebut profesi karena terdapat persyaratan-persyaratan khusus yang harus dipenuhi sehingga suatu bidang pekerjaan dapat disebut sebagai profesi. Profesi pada hakikatnya adalah suatu pernyataan atau suatu janji terbuka yang menyatakan 
bahwa seseorang itu mengabdikan dirinya pada suatu jabatan atau pelayanan karena orang tersebut merasa terpanggil untuk menjabat pekerjaan itu. (Susanto, 2020: 13-14).

Menurut Noor Jamaluddin (1978: 1) Guru adalah pendidik, yaitu orang dewasa yang bertanggung jawab memberi bimbingan atau bantuan kepada anak didik dalam perkembangan jasmani dan rohaninya. Guru merupakan suatu profesi, yang berarti suatu jabatan yang memerlukan keahlian khusus sebagai guru dan tidak dapat dilakukan oleh sembarang orang di luar bidang pendidikan. Walaupun pada kenyataannya masih terdapat guru yang tidak memiliki latar belakang pendidikan bidang keguruan. (Susanto, 2020: 1617).

\section{PERAN GURU SEBAGAI SEBUAH PROFESI}

Guru merupakan suatu profesi, yang berarti suatu jabatan yang memerlukan keahlian khusus sebagai guru dan tidak dapat dilakukan oleh sembarang orang di luar bidang pendidikan. Walaupun pada kenyataannya masih terdapat guru yang tidak memiliki latar belakang pendidikan bidang keguruan. (Susanto, 2020: 17). Guru yang piawai dalam melaksanakan profesinya dapat disebut sebagai guru yang kompeten dan profesional. Komptensi profesional merupakan pekerjaan yang hanya dapat dilakukan oleh seorang yang mempunyai kualifikasi akademik, kompetensi dan sertifikat pendidik sesuai dengan persyaratan untuk setiap jenis dan jenjang pendidikan tertentu. Kompetensi profesional merupakan kemampuan dasar yang harus dimiliki oleh seorang guru. (Susanto, 2020: 63).

Hak dan kewajiban guru ini dituangkan dalam pasal UU No. 14 Tahun 2005 tentang guru dan dosen sehingga setiap guru mendapatkan perlindungan terhadap hak yang dimiliki dan kewajiban yang harus dilaksanakan. Jabatan guru memiliki banyak tugas, baik yang terikat oleh dinas maupun di luar dinas dalam bentuk pengabdian. Tugas guru tidak hanya sebagai suatu profesi, tetapi juga sebagai suatu tugas kemanusiaan dan kemasyarakatan. Tugas guru sebagai suatu profesi menuntut kepada guru untuk mengembangkan profesionalitas diri sesuai perkembangan ilmu pengetahuan dan teknologi. Djaramah (2000: 42-49) menguraikan banyak peranan yang dijalankan sebagai pendidik, yaitu 1) Korektor, peran ini mengharuskan guru memahami betul permasalahan dalam proses pendidikan; 2) Inspirator, guru dapat memberikan ilham yang baik bagi kemajuan belajar peserta didik; 3) 
Informan, guru harus dapat memberikan informasi perkembangan ilmu pengetahuan dan teknologi; 4) Organisator, guru merupakan organisator terkait pengelolaan proses pembelajaran; 5) Motivator, guru hendaknya mampu mendorong peserta didik agar bergairah dan aktif belajar; 6) Inisiator, guru harus dapat menjadi pencetus ide-ide kemajuan dalam pendidikan dan pengajaran; 7) Fasilitator, guru diharuskan untuk dapat memfasilitasi peserta didik dalam proses belajar mengajar; 8) Pembimbing, kehadiran guru di sekolah adalah untuk membimbing peserta didik menjadi manusia dewasa susila yang cakap; 9) Demonstrator; 10) Pengelola kelas, guru hendaknya dapat mengelola kelas dengan baik; 11) Mediator, guru harus memahami begaimana siswa berinteraksi dan merespon suatu keadaan; 12) Supervisor, guru harus menunjukkan kemampuan untuk menawarkan alternatif solusi atas permasalahan yang ditemukan; 13) Evaluator, guru setidaknya dihadapkan pada dua proses penting. Dalam UU No. 14 Tahun 2005 tentang guru dan dosen adapun hak yang dimiliki oleh seorang guru, yaitu 1) Memperoleh penghasilan diatas kebutuhan hidup minimum dan jaminan kesejahteraan sosial, 2) Mendapatkan promosi dan penghargaan sesuai dengan tugas dan prestasi kerja, 3) Memperoleh perlindungan dalam melaksanakan tugas dan hak atas kekayaan intelektual, dll. Adapun kewajiban yang dimiliki oleh seorang guru, yaitu 1) Merencanakan Pembelajaran, 2) Mengambangkan dan meningkatkan kualifikasi akademik dan kompetensi secara berkelanjutan sejalan dengan perkembangan ilmu pengetahuan, teknologi dan seni, 3) Memelihara dan memupuk persatuan dan kesatuan bangsa, dll. (Susanto, 2020: 39-48).

\section{GURU INDONESIA DAN TANTANGAN PROFESIONALISME}

Penilaian terhadap profesi guru juga sangat dipengaruhi oleh kebijakan pemerintahan suatu negara. Beberapa negara seperti Jepang dan Korea sangat menjunjung profesi guru, sehingga mereka yang ingin masuk ke profesi tersebut harus melalui pendidikan formal sesuai bidang profesi dengan persyaratan yang berat. Di Korea Selatan misalnya untuk bisa masuk sekolah keguruan harus melewati seleksi yang ketat dan standar yang tinggi. Sedangkan di Jepang, guru PNS pernah menjadi golongan PNS yang mendapat gaji paling tinggi. Berbagai perlakuan dan kebijakan di kedua negara tersebut menempatkan profesi guru menjadi sejajar dengan profesi lainnya. Di Indonesia penghargaan terhadap 
profesi guru belumlah sebaik kedua negara tersebut, akan tetapi sejak diterapkannya kebijakan sertifikat guru profesi guru mengalami kemajuan signifikan. Meskipun demikian, berdasarkan banyak studi menunjukkan belum ada korelasi langsung program sertifikasi guru (terutama jalur PLPG) dengan peningkatan kualitas pendidikan. (Susanto, 2020: 21). Menurut saya, kalau seorang guru tidak memiliki sikap profesional nya maka akan berdampak pada dirinya sendiri ataupun kepada murid yang diajarnya.

Kompetensi profesional merupakan kemampuan dasar yang harus dimiliki oleh guru. Ada beberapa pandangan ahli tentang kompetensi profesional guru. Menurut Cooper (1984:15) terbagi kedalam 4 komponen kompetensi dasar, yakni 1) Mempunyai pengetahuan tentang belajar dan tingkah laku manusia; 2) Mempunyai pengetahuan dan menguasai bidang studi yang dibinanya; 3) Mempunyai sikap yang tepat tentang diri sendiri, sekolah, teman sejawat dan bidang studi yang dibinanya; 4) Mempunyai keterampilan keterampilan dalam teknik mengajar. Sedangkan menurut Depdibud (1980) ada 10 kemampuan dasar guru, yaitu 1) Penguasaan bahan pelajaran beserta konsep-konsep dasar keilmuaanya; 2) Pengelolaan program belajar mengajar; 3) Pengelolaan kelas; 4) Pengelolaan program belajar mengajar; 5) Penguasaan landasan-landasan kependidikan; 6) Pengelolaan interaksi belajar mengajar; 7) Penilaian prestasi siswa; 8) Pengenalan fungsi dan program bimbingan dan penyuluhan; 9) Penganalan dan penyelenggaraan administrasi sekolah; 10) Pemahaman prinsip-prinsip dan pemanfaatan hasil penelitian pendidikan untuk peningkatan mutu pelajaran. (Susanto, 2020: 63-64).

\section{SIMPULAN}

Profesi juga diartikan sebagai suatu jabatan atau pekerjaan tertentu yang mensyaratkan pengetahuan dan keterampilan khusus yang diperoleh dari pendidikan akademis yang intensif. Guru yang piawai dalam melaksanakan profesinya dapat disebut sebagai guru yang kompeten dan profesional. Dalam pasal UU No. 14 Tahun 2005 tentang guru dan dosen adapun hak yang dimiliki oleh seorang guru, yaitu 1) Memperoleh penghasilan diatas kebutuhan hidup minimum dan jaminan kesejahteraan sosial, 2) Mendapatkan promosi dan penghargaan sesuai dengan tugas dan prestasi kerja, 3) Memperoleh perlindungan dalam melaksanakan tugas dan hak atas kekayaan intelektual, dll. Adapun kewajiban yang 
dimiliki oleh seorang guru, yaitu 1) Merencanakan Pembelajaran, 2) Mengambangkan dan meningkatkan kualifikasi akademik dan kompetensi secara berkelanjutan sejalan dengan perkembangan ilmu pengetahuan, teknologi dan seni, 3) Memelihara dan memupuk persatuan dan kesatuan bangsa, dll. kalau seorang guru tidak memiliki sikap profesional nya maka akan berdampak pada dirinya sendiri ataupun kepada murid yang diajarnya. Kompetensi profesional merupakan kemampuan dasar yang harus dimiliki oleh guru. Ada beberapa pandangan ahli tentang kompetensi profesional guru. Menurut Cooper (1984:15) terbagi kedalam 4 komponen kompetensi dasar, yakni 1) Mempunyai pengetahuan tentang belajar dan tingkah laku manusia; 2) Mempunyai pengetahuan dan menguasai bidang studi yang dibinanya; 3) Mempunyai sikap yang tepat tentang diri sendiri, sekolah, teman sejawat dan bidang studi yang dibinanya; 4) Mempunyai keterampilan keterampilan dalam teknik mengajar. 


\section{REFERENSI}

Efendi, I., Prawitasari, M., \& Susanto, H. (2021). Implementasi Penilaian Pembelajaran Pada Kurikulum 2013 Mata Pelajaran Sejarah. Prabayaksa: Journal of History Education, 1(1), 21-25.

Susanto, H. (2020). Profesi Keguruan. Banjarmasin: FKIP Universitas Lambung Mangkurat.

Susanto, H., \& Akmal, H. (2018). Efektivitas Penggunaan Aplikasi Pembelajaran Berbasis Mobile Smartphone Sebagai Media Pengenalan Sejarah Lokal Masa Revolusi Fisik Di Kalimantan Selatan Pada Siswa Sekolah Menengah Atas. HISTORIA: Jurnal Program Studi Pendidikan Sejarah, 6(2), 197-206.

Susanto, H., Irmawati, I., Akmal, H., \& Abbas, E. W. (2021). Media Film Dokumenter Masuknya Islam Ke Nusantara dan Pengaruhnya Terhadap Keterampilan Berpikir Kritis Siswa. HISTORIA: Jurnal Program Studi Pendidikan Sejarah, 9(1).

Syaharuddin, S., \& Susanto, H. (2019). Sejarah Pendidikan Indonesia (Era Pra Kolonialisme Nusantara sampai Reformasi). Banjarmasin: FKIP Universitas Lambung Mangkurat.

Sidiq, U. (2018). Etika \& Profesi Keguruan. Tulungagung: STAI Muhammadiyah.

Sutarsih, C. (2012). Etika Profesi. Direktorat Jenderal Pendidikan Islam Kementrian Agama. 